\title{
Research-based learning in education studies: Design inquiry using group e-Portfolios based on blogs
}

\author{
Victoria I. Marín \\ University of Oldenburg, Germany
}

\begin{abstract}
Research-based learning (RBL) is an approach that aims to engage students in research activities within their study discipline. Since this method puts the focus on the learner, Web 2.0 tools are considered to provide good support in enhancing collaboration processes, which are necessary in conducting research in real-life situations. The link between RBL and the use of digital technologies in higher education has not yet been extensively empirically explored. Therefore, the main aim of this study, based on a project-based university seminar, was to explore the possibilities of group e-Portfolios based on blogs, within the framework of a concrete form of RBL in education studies, the design-inquiry approach. The study employed mixed methods, consisting of quantitative and qualitative data collected via a student questionnaire, and further qualitative data collected from the group blogs and the students' final reflections. The results show the possibilities and challenges of using ePortfolios based on blogs for RBL processes. The article concludes by providing guidelines and recommendations and presents a framework that connects the models used in the study.

Implications for practice or policy:

- Learning processes with group e-Portfolios based on blogs should include a phase of familiarisation with the tool and regular practice in the classroom, accompanied by simple resources to support the process and to improve students' self-confidence with their digital competence.

- Educational practitioners should provide opportunities for practice with the structure of group e-Portfolios based on blogs and documentation of findings, and for regular (peer) feedback to encourage new perspectives and ensure a successful investigation process.
\end{abstract}

Keywords: research-based learning, education studies, design inquiry, group e-Portfolios, blogs, mixed methods

\section{Introduction}

Implementing research-based learning (RBL) in higher education curricula enables students to "gain experience in planning and carrying out research, learn research skills appropriate to the discipline, and pursue and present research" (Brew, 2013, p. 605). The benefits of RBL include student outcomes (improved skills, matured dispositions, and enhanced knowledge and understanding); and student experiences (engagement and relatedness, efficacy and competence, and a feeling of autonomy) (van der Rijst, 2017). Research-based education is viewed as a cluster of teaching and learning approaches (e.g., project-based learning, problem-based learning, case-based learning) in which students engage actively in inquiry or research activities (van der Rijst, 2017).

Considering educational professionals as agents of change in education, they are expected to design new ways for achieving educational goals (Mor \& Mogilevsky, 2013a,b). For that purpose, creative, proactive and innovative skills are needed in order to design new learning solutions (practices, activities, resources and tools) based on scientific foundations. Therefore, an approach in line with design research or designbased research (DBR) seems to be suitable in the field (de Benito \& Salinas, 2016; Easterday, Rees Lewis, \& Gerber, 2018; Reinmann, 2018; The Design-Based Research Collective, 2003). Similar to inquiry-based learning in the model of scientific investigation, a design-inquiry approach would adopt the form of DBR in education to mimic the structure of an educational design study (Mor \& Mogilevsky, 2013a,b).

As problem-oriented or enquiry-oriented, RBL involves productive and self-organised learning, which may fit well with the appropriate design of learning activities supported by Web 2.0 digital tools (Dürnberger, 
Reim, \& Hofhues, 2011). Those tools enable learners to be producers, by creating their own materials, and enhance collaboration between individuals (Bates, 2011; Conole \& Alevizou, 2010). A suitable example is e-Portfolios, which may support the objectives of RBL by enabling a dynamic mapping and representation of the research and learning process (Muckel, Heidkamp, Kergel, Hartong, \& Brunner, 2014), whilst at the same time, facilitating the process of enhancing digital skills. From the set of tools that could be used for the purpose of creating and maintaining an e-Portfolio, blogs have often been used successfully in higher education (Cabero, Meneses, \& Regaña, 2009; Jimoyiannis, Schiza, \& Tsiotakis, 2018; Tur \& Urbina, 2014; Yang \& Chang, 2012). e-Portfolios based on blogs offer broad possibilities for designing and developing new artefacts suitable to use in different educational contexts, enabling future educational professionals to develop important skills needed in their field, such as critical thinking, problem solving, creativity, communication or collaboration skills (Jimoyiannis, 2012), all of which are also expected in RBL processes.

Therefore, in this study we present a course design in education studies in which we explore the implementation of e-Portfolios based on blogs for a group RBL approach. The findings yield practical guidelines and recommendations for university teachers for the design of RBL activities using group ePortfolios, along with a theoretical contribution in the form of a framework.

\section{Theoretical framework}

\section{The design-inquiry approach as RBL format}

Planning RBL involves targeting different kinds of educational objectives (Aditomo, Goodyear, Bliuc, \& Ellis, 2013). The most common are to acquire and/or apply topic-specific knowledge and develop research and professional skills. However, other educational goals, such as developing collaboration skills, encouraging critical thinking and self-regulated learning skills, as well as communication or presentation skills, may be also embedded. In order to address those objectives, it is necessary to provide students with real-world problems in the form of research activities "that mimic the forms of knowledge creation and dissemination in their disciplines and professional areas” (Healey \& Jenkins, 2009, p. 23).

In the field of education, the educational DBR approach seems to be a suitable RBL method to develop, implement and evaluate different kinds of products or artefacts (such as educational materials, lesson plans, online course) that are intended to solve a problem or address a particular situation (Aditomo et al., 2013; de Benito \& Salinas, 2016). That is done by combining empirical educational research with theory-driven design of learning environments, which makes it an important methodology for understanding how, when, and why educational innovations work in practice (The Design-Based Research Collective, 2003). According to Easterday et al. (2018, p. 21), educational DBR is:

a meta-methodology [...] to create practical interventions and theoretical design models through a design process of focusing, understanding, defining, conceiving, building, testing and presenting, that recursively nests other research processes to iteratively search for empirical solutions to practical problems of human learning.

Figure 1 (adapted from Easterday et al., 2018) presents the content of each phase.

\begin{tabular}{|c|c|c|c|c|c|c|}
\hline Focus & Understand & Define & Conceive & Build & Test & Present \\
\hline $\begin{array}{l}\text { - Bound the scope of } \\
\text { the project }\end{array}$ & $\begin{array}{l}\text {-Study learners, } \\
\text { contexts, needs } \\
\text { and existing } \\
\text { solutions } \\
\text { - It nestes: grounded } \\
\text { theory, literature } \\
\text { review }\end{array}$ & $\begin{array}{l}\text {-Specify the } \\
\text { problem, including } \\
\text { learning goals, } \\
\text { asssessment and } \\
\text { constraints }\end{array}$ & $\begin{array}{l}\text {-Draft a plan for the } \\
\text { solution }\end{array}$ & $\begin{array}{l}\text { - Create the solution } \\
\text { as a usable } \\
\text { prototype }\end{array}$ & $\begin{array}{l}\text { - Evaluate the } \\
\text { efficacy of the } \\
\text { solution } \\
\text {-It nestes: } \\
\text { experiment }\end{array}$ & $\begin{array}{l}\text { - Communicate to } \\
\text { key stakeholders }\end{array}$ \\
\hline
\end{tabular}

Figure 1. The DBR phases. Note: Design phases are carried out iteratively and not necessarily in a linear way, and the design process includes recursively nested processes. 
The application of the pedagogy of RBL to the scientific paradigm of DBR yields the cycle of design inquiry of learning (DIL), which consists of the following phases (Mor \& Mogilevsky, 2013b, p. 3):

- $\quad$ Imagine, by concreting the educational challenge to be addressed.

- Investigate, by analysing the context and identifying the suitable pedagogical approach to the redefined educational challenge.

- Inspire, by reviewing previous examples and applying the lessons learned from them to the current project.

- Ideate a conceptual solution.

- Prototype the solution by implementing it.

- Evaluate the design to verify that its objectives are fulfilled and to identify areas for improvement.

- Reflect on the design process, the related learning experiences and their outcomes.

Design is considered in this context as "the informed creative practice of devising courses of action aimed at changing existing situations into desired ones" (Mor \& Mogilevsky, 2013a, p. 235). In university settings it adopts the format of a learning design studio (LDS), where students work in groups on projects of their own choice and outline a techno-pedagogical innovation addressed to the chosen challenges (Mor \& Mogilevsky, 2013b), which is our focus in the study.

\section{e-Portfolio frameworks}

It has been argued that e-Portfolios are a powerful digital tool for the enhancement of complex and authentic tasks like those involving group RBL processes (Roberts, Maor, \& Herrington, 2016). They have been also considered as tools for creativity and assessment in higher education (Senger \& Kanthan, 2012). A definition of an e-Portfolio is the following:
A flexible, evidence-based tool that engages students in a process of continuous reflection and collaborative analysis of learning. As written text, electronic display, or other creative projects, the portfolio captures the scope, richness, and relevance of students' intellectual development, critical judgment, and academic skills. (Zubizarreta, 2009, p. 20)

The topic has also been well covered by different literature reviews on empirical studies of e-Portfolios where the positive effects on learning were highlighted, such as supporting skill development; providing evidence of learning, feedback, assessment; developing psychological emotions (personal accomplishment, satisfaction, pride); or easing portability and sharing, organisation and privacy (Butler, 2006); and where recurrent themes in e-Portfolio higher education practices were identified, namely curricular integration, infrastructure, motivation and pedagogical goals, scaffolds, assessment, reflection and portfolio learning (Panke, 2014).

There are different frameworks that are used to describe e-Portfolio practices. Zubizarreta (2009) considers documentation, reflection and collaboration as key overlapping processes enhanced by e-Portfolios. Therefore, students building an e-Portfolio should have learned to document their learning, to reflect on it and to work collaboratively with other students and/or teachers. Barrett (2010) describes three progressive levels in the development of an e-Portfolio: (a) the digital conversion and collection of artefacts; (b) the process, documentation and reflection on learning; and (c) the production and documentation of achievement. Coromina, Sabate, Romeu, and Ruiz (2011) outline four steps in the creation of the ePortfolio. In the first two, the e-Portfolio is contextualised and created as process, which focuses on the collection of artefacts and the reflection on concrete evidence. In the last two, the e-Portfolio is created and presented as product, which focuses on demonstrating the learning results and their retrospective (and prospective) reflection as a final production for evaluation. Both perspectives are considered complementary and applicable at different stages in students' academic work (Jimoyiannis \& Tsiotakis, 2016; Tur \& Castañeda, 2016). Conceptual models for the design and implementation of e-Portfolio practices are also to be found in the literature (e.g., Jimoyiannis, 2012; Jimoyiannis \& Tsiotakis, 2016).

\section{e-Portfolios with blogs in higher education}

Blogs, as one of the possible infrastructures for e-Portfolios (Panke, 2014), have been widely used for some time now, and numerous studies using blogs in higher education have been reported (e.g., Churchill, 2009; 
Hemmi, Bayne, \& Land, 2009; Jimoyiannis, 2012). Blogs have been suggested as a possible easy-to-use technological platform to create e-Portfolios (Cabero, López Meneses, \& Jaén, 2013; González Sánchez \& García Muiña, 2011; Jimoyiannis, 2012), and as Web 2.0 tools, they promote a user-centric information infrastructure that emphasises participation and action over presentation and passivity (Brown \& Adler, 2008). This openness has showed positive implications in courses (collaboration, sharing and learning empowerment), but also has downsides, when related to assessment (anxiety and competitiveness) (Tur \& Urbina, 2014). Private blogging environments could be considered as an alternative (Hemmi et al., 2009). One of the research areas is students' perceptions of the use of blogs for e-Portfolios. Some researchers report positive student perceptions of using blogs to enhance learning and peer interaction (Churchill, 2009; Halic, Lee, Paulus, \& Spence, 2010; Shana \& Abulibdehb, 2015; Tur \& Marín, 2015; Yang \& Chang, 2012); as well as a way of developing their digital skills (Goktas \& Demirel, 2012; Neira-Piñeiro, Villalustre, \& Del-Moral, 2013). Churchill's (2009) study shows that students valued being able to view the work of others and receive comments on their work the most. Negative views are also expressed in the literature, with one of the main concerns being the unfamiliarity with technological platforms (O'Connell \& Dyment, 2016; Roberts et al., 2016).

Another line of research involves the development of key skills, such as critical thinking and reflection (Jimoyiannis, 2012; Jimoyiannis et al., 2018; Roberts et al., 2016), and interpersonal abilities (peer support, collaboration, teamwork skills). Chang and Chang (2014) and He, Zhang, Strudler, and Means (2012) reported the development of positive peer support and collaboration around blog activities. In the study by Neira-Piñeiro et al. (2013), students improved their teamwork skills, as well as their critical and self-critical skills when writing in e-Portfolios based on blogs. In a study of group e-Portfolios, students' skills in working collaboratively in a group project allowed them to become aware of their own mistakes, facilitated self-assessment, and provided evidence of their learning progress (Vázquez-Cano, López Meneses, \& Jaén Martínez, 2017). Jimoyiannis (2012) showed that group blogs supported the collaborative construction of knowledge and enhanced opportunities for improving peer interaction and collaboration skills. Deng and Yuen (2013) reported the influence of the level of social bonding on the differences of participation in blogs.

Previous familiarity with the blog platform, time and support for using blogs for academic purposes and as a dialogue, allowing for a range of security settings, and academic blogging meaningful activities in connection with assignments (assessment) to engage and motivate students are some of the highlighted aspects to be considered when designing learning activities with blogs (Churchill, 2009; Deng \& Yuen, 2011; Roberts et al., 2016). One of the major weaknesses of e-Portfolios based on blogs reported in many studies, is that they are time-consuming and require much effort compared to other ways of working and assessing (López Meneses, Vázquez-Cano, \& Jaén Martínez, 2017; Roberts et al., 2016; Salinas \& Marín, 2016).

\section{Research gap}

Critical thinking, problem solving, creativity, communication and collaboration skills are key skills for education students that may well supported by e-Portfolios based on blogs in RBL processes. However, whilst it has been argued they can conveniently be used for RBL (Reinmann, 2009; Roberts et al., 2016; Voll, 2018), almost no study was found related to the support of blogs for group e-Portfolios in RBL practices in higher education, or the pedagogical aspects to consider when designing RBL learning tasks supported by e-Portfolios based on blogs, especially in a DBR approach.

Therefore, the aim of the study was to explore the possibilities and benefits of group e-Portfolios based on blogs for a DBR project in education studies. The main research question was: "How do e-Portfolios based on blogs support group-based RBL processes and products?". In addition, the following research subquestions were explored:

- How are e-Portfolios based on blogs used by different groups, in terms of group dynamics?

- How do groups and individuals value working according to group-based RBL processes and products using e-Portfolios based on blogs?

- Which educational and design aspects should be considered when planning group-based RBL processes and products supported by e-Portfolios based on blogs? 


\section{The study}

\section{Context}

The study was conducted during an on-site course on theories and models of instructional design (ID) in the Master of Educational Science program (2 years) at a German University. The course was offered in English as part of a compulsory module specialising in lifelong learning and education management. The goal of the course is to develop competence in designing, producing, implementing and evaluating educational programs supported by technology, according to the ADDIE ID model (Analysis, Design, Development, Implementation and Evaluation) (Dick, Carey, \& Carey, 2015). The course is designed to be project-based and lasts for 14 weeks, with both face-to-face and out-of-class sessions to work in groups. The project included the first three phases of the model (Analysis, Design and Development) as part of a DBR process.

\section{LDS as a DBR methodological approach}

Following a DBR approach, the students applied the theoretical ID model in the group projects, whilst simultaneously learning about the model as part of the course content. As the LDS format states, the topic for the project was open, and students could choose it according to their interests, in the first phase (imagine), which is identified as focus in DBR. They needed to study the target group for their envisaged product, choose the delivery method and analyse the context (investigate, which corresponds in DBR to understand. They were required to specify the problem and design, produce and present a concrete final solution for it (an initial version of the prototype), for example, a part of an online or blended learning course, a collection of digital materials, or an online environment conceived as a learning community or as a community of practice to their classmates and to the teacher (phases of ideate and prototype, in DBR: define, conceive, build and present). Considering the model for RBL decision-making posed by Brew (2013), the following pedagogical decisions were made regarding the project:

- The learning outcome of the course was set, but how this outcome would be achieved was rather open.

- There was enough freedom so that each group developed the product as they considered best:

○ The field of knowledge was unspecified and negotiable.

- Students chose the topic, although it was agreed with the lecturer.

- Students decided on the goal for their project.

- The product was structured, but negotiated as it was developed.

Inquiry was open-ended.

- Students decided their audience and output.

- Assessment was controlled by the lecturer, though negotiated.

- The work could result in knowledge that is new to the student, but eventually also to the discipline and society.

The process was accompanied by an institutionally supported WordPress blog for each group, conceived as their project e-Portfolio for their LDS. In the course, group blogs were configured so that all the students could read and comment on them, but students could create new content only in their own group blog. The blogs were configured as private, in the sense that they were not visible publicly outside the course. The lecturer also used the blog to provide formative feedback during the process.

Since the students were mostly unfamiliar with WordPress, an introduction to WordPress was provided in the first session and suggestions on how to structure the project in the blog were made. As in Mor and Mogilevsky (2013a), the design-inquiry process was supported by diverse web tools and resources offered by the teacher in a main blog - for instance, a concept map that provided an overview of the phases in the project and suggestions for suitable technology tools or procedures to use in each phase, as well as an idea for student roles when organising the groups (Marín, 2017). 


\section{Methodology}

The intentional sample consisted of the 15 postgraduate German university students in their second year of the above-mentioned master that were participating in the course. Most were female, within the age range of 22-40 years old and with familial and/or professional responsibilities. Most of them were used to working without digital tools both at the university and in other personal and/or professional contexts. However, they had developed general knowledge around educational technology in a module from the previous semester. During the semester under study, the 15 participants were divided into 5 groups for the group project.

A mixed methodology was applied, using quantitative and qualitative data collection and analysis methods. Quantitative data was collected via an anonymised student questionnaire (see Appendix), in which students evaluated the use of the e-Portfolio based on blogs according to a Likert scale (from 1: completely disagree to 5: completely agree). The instrument was designed specifically for this study, considering Zubizarreta's (2009) and Barrett's (2010) e-Portfolio models. The analysis of these data was carried out by exploring the descriptive statistics with SPSS version 25. Cronbach alpha coefficient was calculated in order to determine the reliability and internal consistency of the instrument.

The qualitative method included the analysis of the open answers to the student questionnaire and the individual and group reflections written in their e-Portfolio. It should be noted that these reflections were not exclusively related to the support of group-based RBL processes and products by e-Portfolios based on blogs. Therefore, not all students reflected deeply on this aspect, which represents a limitation for the analysis regarding some items. Data analysis was performed using procedures for qualitative thematic analysis (Braun \& Clarke, 2006) with the MAXQDA 2018 software. First, the scanned student questionnaire answers and parts referring to the e-Portfolios from the blog reflections were included as documents in the software to be analysed. Then, the analysis was done firstly in a deductive way based on the e-Portfolio model of Zubizarreta (2009) (fundamental components: documentation, reflection and collaboration), and secondly in an inductive form to identify new themes within the data. The structure of the themes changed continuously during the analysis, including the addition and combination of themes. However, the classification of relevant information was done according to the particular research subquestions.

Ethical issues were taken into account by explaining the research goals to the participants, asking for their voluntary participation in the anonymised questionnaire, and making it clear that this evaluation would not be considered for any purposes other than the current study. Written consent to use the content of the blogs for research purposes was also obtained from a representative of each of the five groups, in agreement with the rest of their group.

\section{Results and discussion}

We present and discuss the results in this section, bearing in mind the main research question, which concerns the support of group-based RBL processes and products by e-Portfolios based on blogs.

A first glance at the descriptive statistics of the data derived from the student perceptions questionnaire (14 out of 15 questionnaires were obtained) shows that most of the groups used the blog tool as a platform for collecting or storing information (INFCOL) $(M=4.29)$ (see Figure 2). Such use includes all the different phases during the whole RBL process, until the conclusion and presentation of the final work: documenting initial ideas, collecting theoretical and empirical information on the topic, and saving information related to their progress. The function used the least by the students was enhancing collaboration inside their own group (COLB) $(M=2.69)$. 


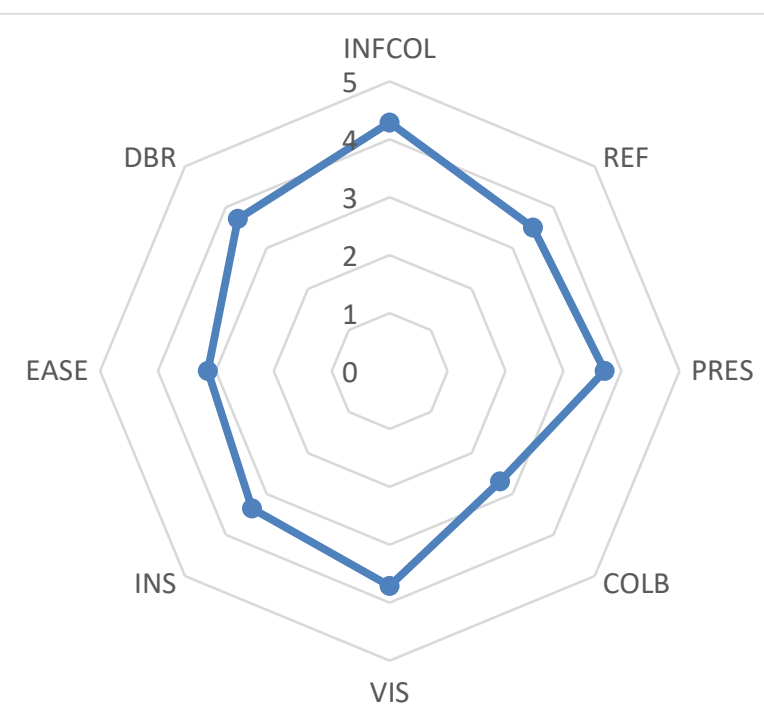

Figure 2. Means of the items in the questionnaire

In general, the students were between neutral and positive concerning other functions of the group ePortfolio, for example, presenting the information in a structured way (PRES), visualising the progress of their project (VIS), and supporting DBR (for the three of them: $M=3.71$ ). Lower mean values were found for the support of reflection (REF) $(M=3.5)$, the provision of insight into the other groups (INS) $(M=$ $3.36)$ and the ease of use (EASE) of the blog tool $(M=3.14)$.

The Cronbach alpha coefficient's value was .719, which is good according to criteria for establishing the internal consistency reliability $(0.7<\alpha<0.9)$, especially in non-confirmatory studies (Bhatnagar, Kim, \& Many, 2014). However, without the element Insight to other groups (INS) the coefficient improves its value (.813).

Table 1 shows how the analysis of the qualitative data supports both Coromina et al.'s (2011) process-andproduct approach to e-Portfolios and the different functions highlighted by Zubizarreta (2009), despite the low values in the quantitative analysis for some of them (especially collaboration).

The source identification of each excerpt in the table is pointed out in parentheses: the letter identifies the data source ( $\mathrm{Q}$ for questionnaire, $\mathrm{R}$ for individual reflections and $\mathrm{G}$ for group reflections) and the number represents a single student in the case of questionnaire and individual reflections, and a group and a member within the group after a point in the case of the group reflections. Since the participation in the questionnaires was anonymous, the numbers in the students' questionnaires do not correspond to the same ones in the reflections. 
Table 1

Functions of e-Portfolios correlated with excerpts from the qualitative data

\begin{tabular}{|c|c|c|}
\hline $\begin{array}{l}\text { e-Portfolio } \\
\text { functions }\end{array}$ & Description & Excerpts \\
\hline $\begin{array}{l}\text { Process: } \\
\text { Documentation } \\
\text { (INFCOL) } \\
\text { (VIS) }\end{array}$ & $\begin{array}{l}\text { Refers to the use of the e- } \\
\text { Portfolio as a tool for } \\
\text { collecting information and } \\
\text { reporting work progress. }\end{array}$ & $\begin{array}{l}\text { We didn't use WordPress as the main communication } \\
\text { platform, we rather collected there our results of the } \\
\text { phases. (G4) } \\
\text { We updated concerning our work progress and we } \\
\text { structured the development of our work. (Q6) }\end{array}$ \\
\hline $\begin{array}{l}\text { Process: } \\
\text { Reflection } \\
\text { (REF) }\end{array}$ & $\begin{array}{l}\text { Concerns the use of the e- } \\
\text { Portfolio for reflection on } \\
\text { the process and product of } \\
\text { the group's project. }\end{array}$ & $\begin{array}{l}\text { We could use the blog posts to reflect on our working } \\
\text { progress. (G4) } \\
\text { We used the blog to collect information and to reflect } \\
\text { on the work progress. (Q5) }\end{array}$ \\
\hline $\begin{array}{l}\text { Process: } \\
\text { Collaboration } \\
\text { (COLB) } \\
\text { (INS) }\end{array}$ & $\begin{array}{l}\text { Refers to issues related to } \\
\text { communication and } \\
\text { working in a group. }\end{array}$ & $\begin{array}{l}\text { Everyone in the group wrote notes and tasks in the } \\
\text { blog. That works. (Q2) } \\
\text { We split the work but we worked sometimes on one } \\
\text { topic or completed the other topics together. (Q9) } \\
\text { Sharing (through the blog) is a good way to work as a } \\
\text { group. (Q10) } \\
\text { Most of the time our group has a meeting to work } \\
\text { together on content... before releasing it online. } \\
\text { (Q11) } \\
\text { Diverse smartphone apps, such as WhatsApp, } \\
\text { functioned as the main communication tools to plan } \\
\text { for meetings. When a team member wasn't able to } \\
\text { attend a course session, we immediately shared and } \\
\text { exchange news and relevant information after the } \\
\text { session. (G4) }\end{array}$ \\
\hline Product (PRES) & $\begin{array}{l}\text { Refers to the e-Portfolio } \\
\text { for the presentation of the } \\
\text { product and as an } \\
\text { assessment tool. }\end{array}$ & $\begin{array}{l}\text { I used the blog to write text and visualise my topics } \\
\text { with pictures. (Q4) } \\
\text { I personally used the blog rather to present the final } \\
\text { results of the work I've done than using it to illustrate } \\
\text { the work process. (Q5) } \\
\text { It is like working on a presentation. (Q11) }\end{array}$ \\
\hline
\end{tabular}

Both the quantitative and qualitative data suggested that most of the groups used different ways of communicating and collaborating (face-to-face meetings and other online communication and collaboration tools), which is consistent with the quantitative data.

On the other hand, the findings reveal different group dynamics in using the group e-Portfolio blog during the RBL process, confirming that process and product perspectives can be complementary in different moments (Jimoyiannis \& Tsiotakis, 2016; Tur \& Castañeda, 2016).

In the next subsections, the findings for each of the research sub-questions are presented, starting with a further exploration of the group dynamics.

\section{Group dynamics of the use of e-Portfolios based on blogs}

Since different group dynamics were identified in the analysis of the quantitative data, the group ePortfolios were analysed to identify differences in their structure and use (Figure 3 ). 

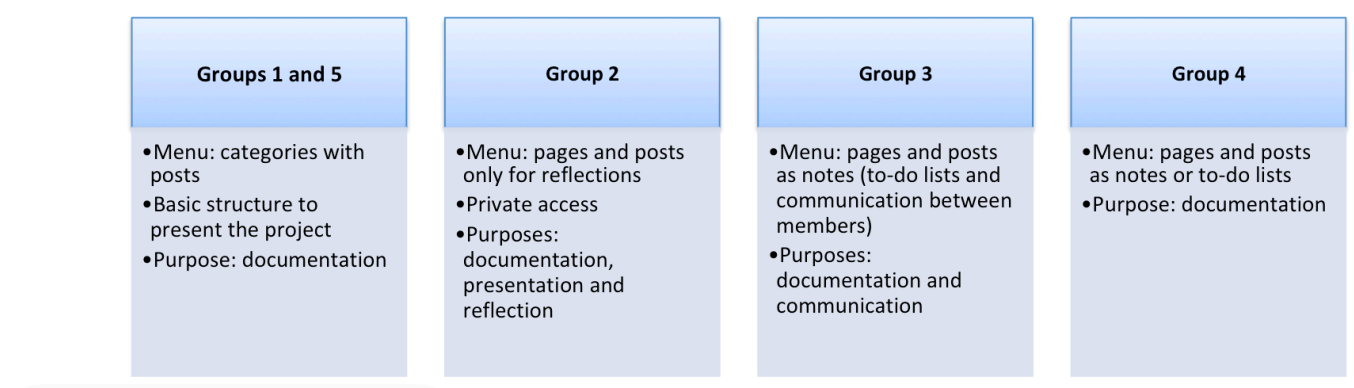

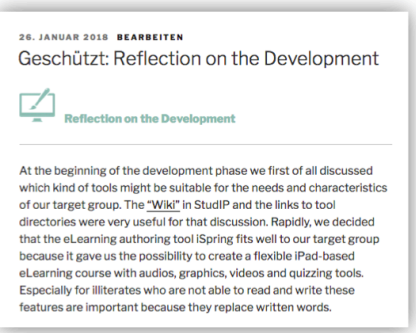

Reflection

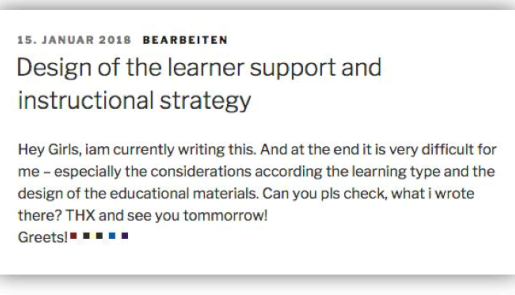

Communication

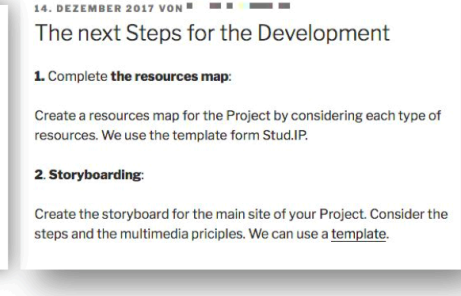

Documentation

Figure 3. Use and structure of the e-Portfolio blogs by each group with examples of blog posts regarding the different components of e-Portfolio according to Zubizarreta (2009)

Following Coromina et al. (2011), two moments can be clearly differentiated in most of the group ePortfolio blogs:

- During the course, the group blog performed as a process e-Portfolio, since students used it as a space to save new information and ideas, in addition to sporadic (or more frequent in the case of Group 2) reflections on the development of the project during the different phases.

- At the delivery moment, after the course, the group blog clearly became a product e-Portfolio. The students took care of the presentation and structure of the information in the blog, prior to being assessed.

After analysing the way of working of groups regarding the e-Portfolio functions, finding out how students appraised the use of e-Portfolios for the RBL approach was the next step to consider.

\section{Group and individual appraisal of group-based RBL work with e-Portfolios based on blogs}

Even though the quantitative mean value for the item related to the suitability of using the e-Portfolio blog for DBR is not very high (3.71), the qualitative analysis of answers to the open questions and blog reflections revealed mainly positive responses, providing some valuable insights into how students considered working with the tool for the project (see Table 2). 
Table 2

Valued characteristics of e-Portfolios based on blogs for RBL

\begin{tabular}{|c|c|}
\hline Characteristics & Excerpts \\
\hline Creative & $\begin{array}{l}\text { A group blog with WordPress is a very creative way for conducting a group } \\
\text { project. I enjoyed [...] to combine the texts with creative elements like pictures, } \\
\text { videos, and other documents. (R2.1) }\end{array}$ \\
\hline \multirow[t]{2}{*}{ Experiential } & I really liked the idea and the way of learning by doing. (G9) \\
\hline & The more we use it, the more we get to know how to use it. (Q7) \\
\hline \multirow[t]{3}{*}{$\begin{array}{l}\text { Acquisition of } \\
\text { digital skills }\end{array}$} & $\begin{array}{l}\text { I am glad that I accepted the challenge because I have learned a lot especially in } \\
\text { the use of sharing tools and collaborative learning (R2.2) }\end{array}$ \\
\hline & Now, after completing our blog I can say that I will be able to create a new \\
\hline & Wordpress-blog concerning another topic in the future. (R2.1) \\
\hline \multirow[t]{2}{*}{$\begin{array}{l}\text { Combination of } \\
\text { theory and } \\
\text { practice }\end{array}$} & $\begin{array}{l}\text { We learned something theoretically about the ID process and after this, we were } \\
\text { putting it into our practice work on the blog. This is why we are satisfied with our } \\
\text { experience in learning to do the activities. (G3) }\end{array}$ \\
\hline & $\begin{array}{l}\text { I enjoyed the opportunity to write texts including theoretical information and } \\
\text { practical experiences [...]. (R2.1) }\end{array}$ \\
\hline Time-consuming & $\begin{array}{l}\text { Creating the WordPress blog in a group was sometimes time consuming because } \\
\text { we had to figure out and agree on the best way to present and manage information } \\
\text { on the blog. (R2.1) }\end{array}$ \\
\hline
\end{tabular}

Creativity is a key skill for educational professionals in so much as they should design innovative learning solutions for educational challenges (Mor \& Mogilevsky, 2013b). Jimoyiannis and Tsiotakis (2016) identified this skill as a way to reflect the complexity of students' learning presence in the e-Portfolio when they co-create their digital artefact with peers. Students in this study took advantage of the Web 2.0 possibilities of blogs by configuring the visual elements from the layout (e.g., adding icons to the titles of pages and entries, incorporating different widgets such as a calendar) and including multimedia and embedded elements (e.g., pictures and embedded PDFs) (see Figure 4).

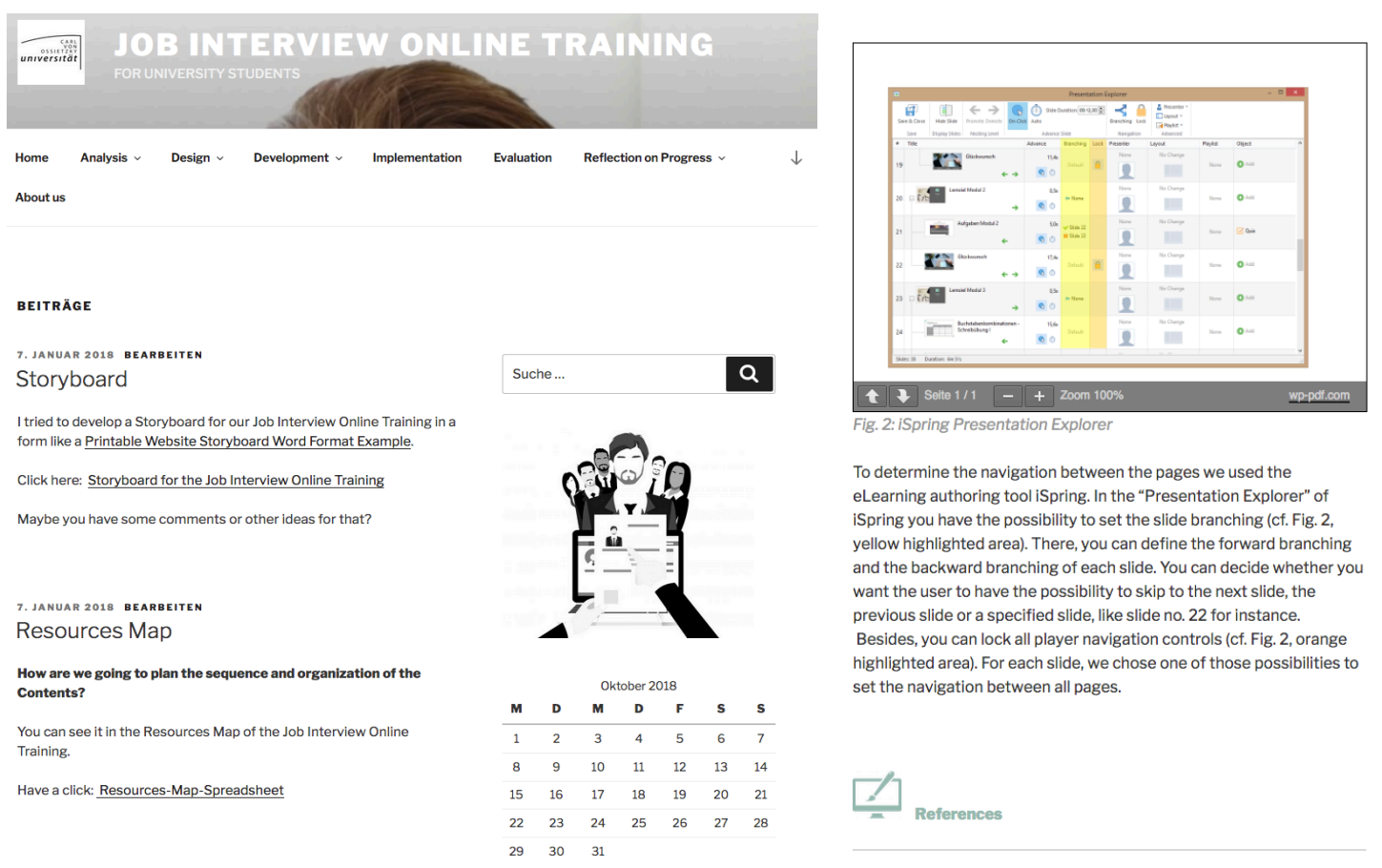

Figure 4. Variety of Web 2.0 possibilities applied by students in their group blogs

Also, the different dynamics between groups reflect diverse ways of using the blogs for learning purposes in a more or less creative way (see above in Figure 4), even though not many of them mentioned that aspect 
in their reflections. Therefore, the claim made by Senger and Kanthan (2012) that e-Portfolios are creative learning tools would also be applicable to this study.

The value of experiential learning and the combination of theory and practice highlight the implementation of the ID principle related to the application of new knowledge by learners (Merrill, 2002). These characteristics are also in line with the educational aims for RBL (van der Rijst, 2017). In addition, the acquisition of digital skills coincides with the findings of Goktas and Demirel (2012). Finally, the task of maintaining a group e-Portfolio is a time-consuming activity that requires much effort; this is not a new finding in our study (see López Meneses et al., 2017; Salinas \& Marín, 2016).

Considering the findings regarding the actual use of the group e-Portfolios and their appraisal by the students, the third research sub-question addressed educational and design aspects.

\section{Educational and design aspects to be considered in designing for learning}

The qualitative analysis highlighted the following educational and design aspects to consider when planning group-based RBL processes supported by e-Portfolios based on blogs (see Table 3).

Table 3

Educational and design aspects for group-based RBL processes supported by e-Portfolios based on blogs

Educational and design aspects

Novelty of using the blog tool for e-Portfolios

Lack of digital skills

Difficulty of use

Combination of discipline content and use of the e-Portfolio

Lack of collaboration between groups

Private vs. open practice

Need for a division of work

Supporting tools for the RBL processes

\section{Excerpts}

In the beginning of my work with the blog I had to read some more information about the functions of WordPress so that I was able to create new blog entries more easily. (R2.1)

For all of us, it was the first time using WordPress and a Blog in general. (G1)

We all think it was an interesting experience, but all of us lacked in skills and experience on how to use and interact on a blog in a meaningful way or present content properly. (G1)

The use of the blog was difficult at first. It is a little bit hard to handle in this short time. (Q3)

For me the blog is not a good tool, because of its confusing interface and structure. (Q6)

The whole idea of the project was new to me: from the work with WordPress to the particular steps of an instructional design process. (R4.1)

It would be desirable to enable more exchange between the groups in order to support each other and get new perspectives and enriching ideas. (G4)

It would be useful to invite the other groups to comment on the blog posts as well to facilitate collaboration. (Q5)

It was quite an effort for me to use WordPress as a tool for the assessment because I had been accustomed to write only to my lecturer before. (R2.2)

[I would have wished for a] clear definition of roles and tasks to do (expectations for the final assessment). (Q8)

We used the main blog at nearly every group meeting to read more about our instructions and the required content. That was very helpful. Besides I liked the parts of the analysis, which illustrated in a descriptive way the starting point of our subject. After that it was easier to develop the steps that based on it. (R4.3) 
Contrary to some previous studies (Cabero et al., 2013; González Sánchez \& García Muiña, 2011), students in this study found the blog tool not very easy to use or intuitive; this can be connected with the feeling of having insufficient digital skills to deal with the tool. In addition, unfamiliarity with the tools has been also found to be a reason for maintaining negative views towards e-Portfolios (O'Connell \& Dyment, 2016; Roberts et al., 2016). Roberts et al. (2016) maintain in their third design principle that implementing them with a strong pedagogical focus from the beginning of a degree will ease this situation and enable students to be more engaged with the e-Portfolio task.

Another main challenge for the novelty of the approach for the students, but at the same time one of the most positive aspects, was linking theory and practice in the e-Portfolio, which coincides with what Voll (2018) found in her study and also with the reasoning from Roberts et al. (2016) that e-Portfolios are suitable to support such complex tasks. Mor and Mogilevsky (2013a) also reported students' difficulty in the concretisation of theories and abstract ideas, but that awareness and the process itself helped them to deal with it.

Regarding collaboration between groups, even though the blogs were configured to be readable by all groups, and peer feedback was encouraged, no collaboration through the blogs was perceived, which is in disagreement with other studies in which peer support occurred and positive social collaboration environment was generated (Churchill, 2009; Deng \& Yuen, 2013; He et al., 2012). Most of the students knew each other before the course, so the reason is unlikely to be the social bonding of the class (Deng \& Yuen, 2013); but most likely to be explained by the face-to-face nature of the course and the fact that collaboration between groups was not an assessment element (Churchill, 2009; Roberts et al., 2016). The need for tasks division is a topic that also appears in Jimoyiannis (2012).

A further issue is that students are not used to openly sharing and collaborating with others, particularly if the work is to be assessed. Therefore, the password-protected e-Portfolio of one of the groups may be explained by this or, as other authors have noted (Tur \& Urbina, 2014), in this case openness could be connected to competitiveness, even though they were provided with a private blogging environment (Hemmi et al., 2009).

Finally, as in Mor and Mogilevsky (2013a), students acknowledged the value of the availability of different tools that were meant to support the design-inquiry process, such as the main blog, which contained recommendations, the overview of questions for the process, and links to other methods and representations.

\section{Guidelines and recommendations}

Derived from the findings presented earlier, Table 4 highlights various design guidelines and recommendations regarding the design of RBL courses focused on DBR with the support of e-Portfolios based on blogs.

These principles add to the ones already proposed by Jimoyiannis (2012) as general good practices for the implementation of e-Portfolios in educational settings, and are concretely specified for the applied RBL process (DBR, and more concretely, DIL); for instance, assigning meaningful and authentic learning activities, providing complete criteria for student assessment and making clear that collaboration and content contribution will be a part of the assessment, offering scaffolding and prompt feedback to the students' contributions, encouraging reflection and collaboration among students, or promoting discussion and ideas sharing. 
Table 4

Guidelines for supporting the development of group e-Portfolios based on blogs for DBR. Correspondence with the DIL cycle is in parentheses.

\begin{tabular}{|c|c|}
\hline DBR phases & Guidelines and recommendations \\
\hline Focus (imagine) & $\begin{array}{l}\text { - Conduct hands-on training on e-Portfolios based on the tool that will be used } \\
\text { for the blogs during face-to-face sessions, first with random content instead of } \\
\text { the actual product work. That could include two of the principles from } \\
\text { Jimoyiannis (2012): the provision of technical assistance to promote students' } \\
\text { participation and the incorporation of detailed instructions. } \\
\text { Familiarise students with the blog tool by working with it on a regular basis. } \\
\text { Start with easy tasks and continue with more complex functions later in the } \\
\text { process, which could include working together in the same blog (using the } \\
\text { comments function, editing the same pages, creating posts from different } \\
\text { roles). Providing time for practice in class (Jimoyiannis, 2012; Roberts et al., } \\
\text { 2016) would also reduce resistance due to time constraints. } \\
\text { Provide resources to support the process and product (e.g., a main blog, an } \\
\text { overview with a concept map, templates for the presentation in the e- } \\
\text { Portfolio), which means giving a conceptual outline and good examples } \\
\text { (Jimoyiannis, 2012). } \\
\text { Clarify the correspondence between the process of the group work and the } \\
\text { structure of the e-Portfolio and connect the activity with the assessment. That } \\
\text { partially overlaps with the recommendation from Roberts et al. (2016) in their } \\
\text { second design principle of ensuring clarity of the task and demonstration of } \\
\text { connection between the e-Portfolio and the students' learning, as well as the } \\
\text { recommendation of providing explicit information regarding the learning } \\
\text { objectives of the e-Portfolio (Jimoyiannis, 2012). } \\
\text { Provide clear definitions of roles and tasks and encourage students to assign } \\
\text { themselves according to their own skills and assets, which is also suggested } \\
\text { by Jimoyiannis (2012). } \\
\text { Incorporate the use of simple tools (e.g., online pinboards for brainstorming) } \\
\text { in class to improve students' self-confidence with their digital competence } \\
\text { whilst making progress together in the first steps of the project. } \\
\text { Ensure a secure atmosphere for students to feel comfortable with their group } \\
\text { e-Portfolio work. Jimoyiannis (2012) adds to it the creation of a culture of } \\
\text { trust and collaboration among students. }\end{array}$ \\
\hline $\begin{array}{l}\text { Understand } \\
\text { (investigate, } \\
\text { inspire) }\end{array}$ & $\begin{array}{l}\text { - Support the documentation of findings from the literature and generation of } \\
\text { questions or description of the situation by students' writing posts. } \\
\text { Offer different templates and patterns to support students in the process of } \\
\text { investigation (in this case: studying learners, contexts and needs). } \\
\text { - Encourage regular peer feedback with concrete tasks through comments on } \\
\text { the other projects to encourage the generation of new ideas. } \\
\text { Provide feedback on posts to enhance a suitable starting point for the } \\
\text { investigation. }\end{array}$ \\
\hline $\begin{array}{l}\text { Define and } \\
\text { conceive } \\
\text { (ideate) }\end{array}$ & $\begin{array}{l}\text { - Support the process of investigation (research design and implementation) by } \\
\text { students' writing posts. } \\
\text { - Offer different templates and patterns to support students in designing their } \\
\text { solutions (e.g., course plan). } \\
\text { - Encourage regular peer feedback to encourage new perspectives on the } \\
\text { process of investigation and incorporate it as part of the assessment of the } \\
\text { product. } \\
\text { - Provide feedback to ensure a successful investigation process. }\end{array}$ \\
\hline
\end{tabular}




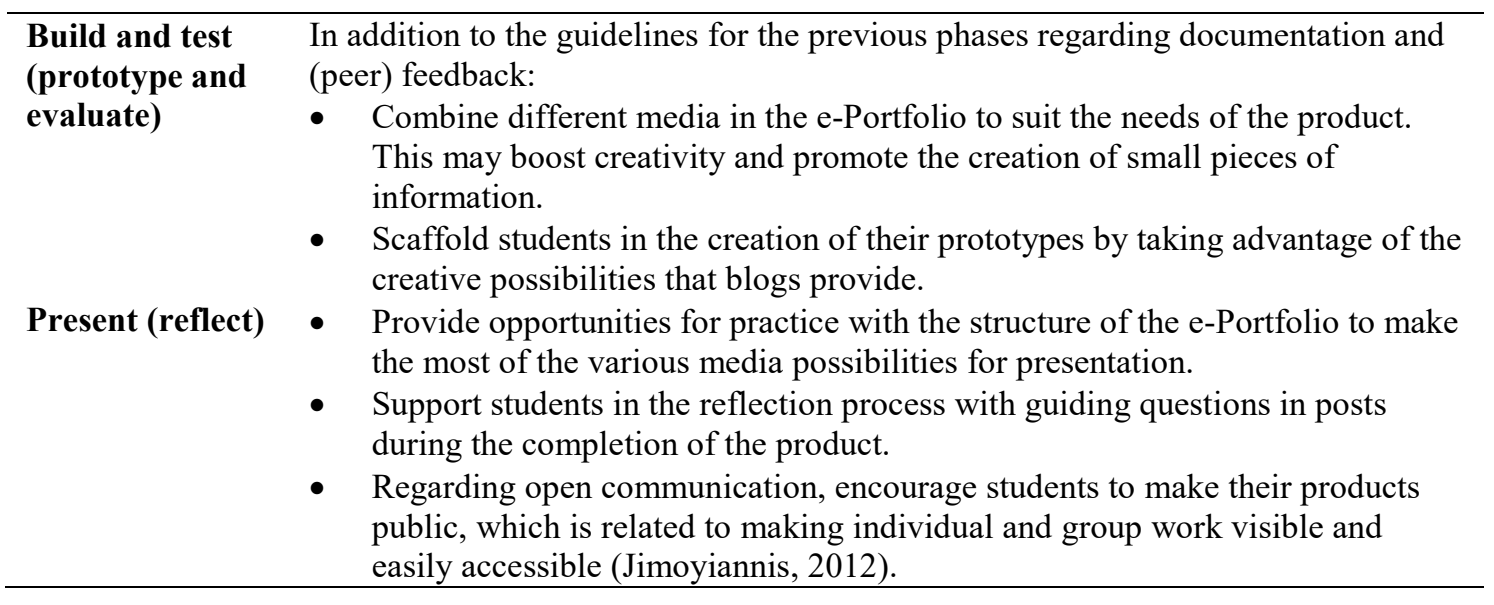

These guidelines are addressed to university teachers or learning designers who would like to apply RBL with a DBR approach and thus, they may apply to other disciplines in which group RBL processes are relevant for a learning product that should be designed.

\section{Proposal of a comprehensive framework}

The results and discussion above enable the author to propose a framework that combines the DBR phases and the IDL concrete approach considering the e-Portfolios models of Zubizarreta (2009) and Coromina et al. (2011) (see Figure 5).

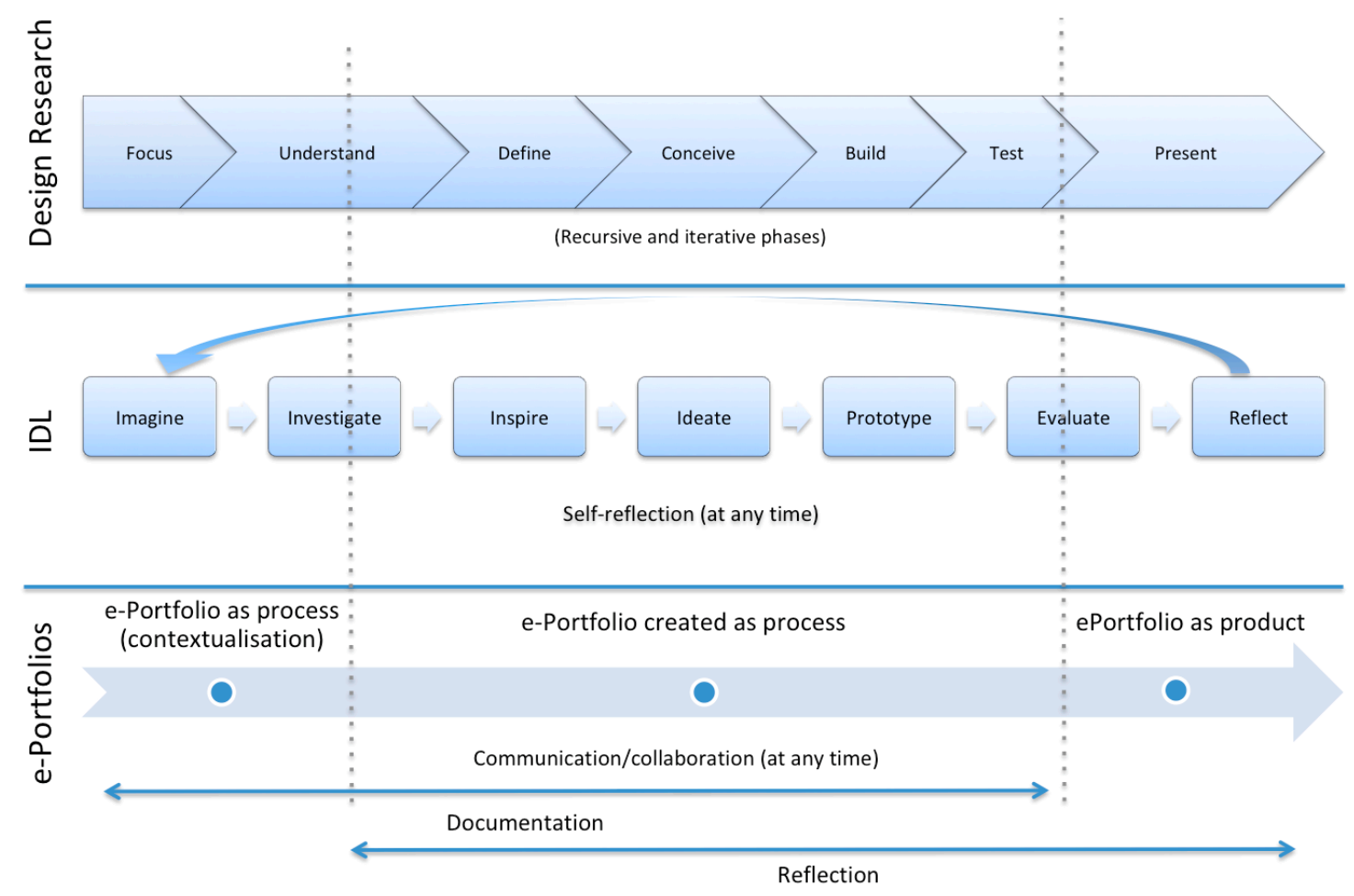

Figure 5. Framework for group e-Portfolios within DBR and IDL approach

The framework presents the practice of group e-Portfolios within the timeline of the IDL model and the DBR phases, presenting an integrated model for RBL using e-Portfolios. The initial steps of focusing and understanding are put into practice with the contextualisation of the e-Portfolio, so that later it is created and maintained as process where collaboration, reflection and documentation may take place during the design (define and conceive), development (build) and implementation (test) of the product. Finally, the e- 
Portfolio as product is presented in the last step where sharing, discussion and final reflections (present) are paramount.

\section{Conclusions and future work}

In the study, the diverse aspects of group e-Portfolios based on blogs for RBL in education studies were explored. Although the cognitive demands of learning the content and performing those very functions and activities in a project at the same time (the actual application of the DBR approach through the LDS) were a challenge for the students, as was the selected blog tool, they appreciated this way of working. RBL supports the development of research activities that are usual in the discipline and, in education, designing, developing, implementing and evaluating learning products based on learning theories and ID models, and the identification of needs in context, is one of them (DBR).

The limitations of the study should also be acknowledged. One of the major ones is the small sample size and its relatively homogeneity in terms of profile, which depended on the students that enrolled in the course. The data analysis has also the limitation that only one researcher was involved in the process; further work should integrate discussion during the process of data analysis to reach more reliable results. On the other hand, not having included collaboration between groups in the design of the learning activity as an element for assessment also seems to be a limitation, which needs to be regarded as a component for future educational practice.

Regarding future work, the support of other teaching and learning approaches focusing on the active participation of learners with the use of e-Portfolios and other digital tools should be explored. Strategies to foster collaboration between groups in RBL processes should also be taken into account to be designed, implemented and evaluated. On the other hand, future studies should consider trialling the method with bigger samples than the current one and to contrast the findings with groups in different disciplines and other universities internationally.

\section{Acknowledgements}

This work has been supported by the Research-Based Learning in Focus Plus - FliF plus project (Forschungbasiertes Lernen im Fokus Plus - FliF plus), with code 01PL16056 of the University of Oldenburg, funded by the Quality Pact for Teaching of the Federal Ministry of Education and Research (BMBF) of Germany.

\section{References}

Aditomo, A., Goodyear, P., Bliuc, A. M., \& Ellis, R. A. (2013). Inquiry-based learning in higher education: Principal forms, educational objectives, and disciplinary variations. Studies in Higher Education, 38(9), 1239-1258. https://doi.org/10.1080/03075079.2011.616584

Barrett, H. (2010). Balancing the two faces of ePortfolios. Educação, Formação \& Tecnologias, 3(1), 614. Retrieved from http://eft.educom.pt/index.php/eft/article/view/161

Bates, T. (2011). Understanding Web 2.0 and its implications for e-learning. In M. J. W. Lee \& C. McLoughlin (Eds.), Web 2.0-based e-learning: Applying social informatics for tertiary teaching (pp. 21-42). Hershey, PA: IGI Global. https://doi.org/10.4018/978-1-60566-294-7.ch002

Bhatnagar, R., Kim, J., \& Many, J. E. (2014). Candidate surveys on program evaluation: Examining instrument reliability, validity and program effectiveness. American Journal of Educational Research, 2(8), 683-690. https://doi.org/10.12691/education-2-8-18

Braun, V., \& Clarke, V. (2006). Using thematic analysis in psychology. Qualitative Research in Psychology, 3(2), 77-101. https://doi.org/10.1191/1478088706qp063oa

Brew, A. (2013). Understanding the scope of undergraduate research: A framework for curricular and pedagogical decision-making. Higher Education, 66(5), 603-618. https://doi.org/10.1007/s10734013-9624-X

Brown, J. S., \& Adler, R. P. (2008). Minds on fire: Open education, the long tail, and Learning 2.0. Educause Review, 43(1), 16-20. Retrieved from https://er.educause.edu/articles/2008/1/minds-on-fireopen-education-the-long-tail-and-learning-20 
Butler, P. (2006). A review of the literature on portfolios and electronic portfolios (Techreport 2006). Palmerston North, New Zealand: Massey University College of Education.

Cabero, J., López Meneses, E., \& Jaén, A. (2013). Los portafolios educativos virtuales en las aulas universitarias. Instrumentos didácticos para la innovación docente y la calidad de los procesos de enseñanza y aprendizaje [Educational e-portfolios in university classrooms: Didactic tools for teaching innovation and quality of teaching and learning process]. Enseñanza \& Teaching, 31(1), 4370. Retrieved from http://revistas.usal.es/index.php/0212-5374/article/view/11604

Cabero, J., Meneses, E. L., \& Regaña, C. B. (2009). Experiencias universitarias innovadoras con blogs para la mejora de la praxis educativa en el contexto europeo [Innovative university experiences with blogs for the improvement of educational praxis in the European context]. RUSC. Revista De Universidad Y Sociedad Del Conocimiento, 6(2). Retrieved from http://www.raco.cat/index.php/RUSC/article/view/140242/191428

Chang, Y. J., \& Chang, Y. S. (2014). Assessing peer support and usability of blogging in hybrid learning environments. Interactive Learning Environments, 22(1), 3-17. https://doi.org/10.1080/10494820.2011.619889

Churchill, D. (2009). Educational applications of Web 2.0: Using blogs to support teaching and learning. British Journal of Educational Technology, 40(1), 179-183. https://doi.org/10.1111/j.14678535.2008.00865.x

Conole, G., \& Alevizou, P. (2010). A literature review of the use of Web 2.0 tools in higher education. Retrieved from http://cloudworks.ac.uk/cloud/view/2294

Coromina, J., Sabate, F., Romeu, J., \& Ruiz, F. (2011). Portafolio digital de aprendizaje: Un nuevo medio de comunicación en la educación [Digital portfolio for learning: A new communication channel for education]. Intangible Capital, 7(1), 116-142. https://doi.org/10.3926/ic.2011.v7n1.p116-142

de Benito, B., \& Salinas, J. (2016). La Investigación Basada en Diseño en Tecnología Educativa [Designbased research in educational technology]. Revista Interuniversitaria de Investigación En Tecnología Educativa, 44-59. https://doi.org/10.6018/riite2016/260631

Deng, L., \& Yuen, A. H. K. (2011). Towards a framework for educational affordances of blogs. Computers and Education, 56(2), 441-451. https://doi.org/10.1016/j.compedu.2010.09.005

Deng, L., \& Yuen, A. H. K. (2013). Blogs in pre-service teacher education: Exploring the participation issue. Technology, Pedagogy and Education, 22(3), 339-356. https://doi.org/10.1080/1475939X.2013.802990

The Design-Based Research Collective. (2003). Design-based research: An emerging paradigm for educational inquiry. Educational Researcher, 32(1), 5-8. https://doi.org/10.3102/0013189X032001005

Dick, W., Carey, L., \& Carey, J. O. (2015). The systematic design of instruction. Boston, MA: Pearson.

Dürnberger, H., Reim, B., \& Hofhues, S. (2011). Forschendes Lernen: konzeptuelle Grundlagen und Potenziale digitaler Medien [Research-based learning: Conceptual foundations and potentials of digital media]. In T. Köhler \& J. Neumann (Eds.), Wissensgemeinschaften. Digitale Medien - Öffnung und Offenheit in Forschung und Lehre (Vol. 60, pp. 209-219). Münster, Germany: Waxmann. Retrieved from http://www.qucosa.de/fileadmin/data/qucosa/documents/7634/19 Dürnberger.pdf

Easterday, M. W., Rees Lewis, D. G., \& Gerber, E. M. (2018). The logic of design research. Learning: Research and Practice, 4(2), 131-160. https://doi.org/10.1080/23735082.2017.1286367

Goktas, Y., \& Demirel, T. (2012). Blog-enhanced ICT courses: Examining their effects on prospective teachers' ICT competencies and perceptions. Computers and Education, 58(3), 908-917. https://doi.org/10.1016/j.compedu.2011.11.004

González Sánchez, R., \& García Muiña, F. E. (2011). Recursos eficaces para el aprendizaje en entornos virtuales en el espacio europeo de educación superior: Análisis de los edublogs [Effective resources for learning in virtual learning environments: The edublogs analysis]. Estudios Sobre Educación, 20, 161-180. Retrieved from https://www.unav.edu/publicaciones/revistas/index.php/estudios-sobreeducacion/article/download/4545/3919

Halic, O., Lee, D., Paulus, T., \& Spence, M. (2010). To blog or not to blog: Student perceptions of blog effectiveness for learning in a college-level course. Internet and Higher Education, 13(4), 206-213. https://doi.org/10.1016/j.iheduc.2010.04.001

He, W., Zhang, S., Strudler, N., \& Means, T. (2012). Integrating a case library with blogs for lesson planning activities. International Journal of Learning Technology, 7(2), 133. https://doi.org/10.1504/IJLT.2012.047979 
Healey, M., \& Jenkins, A. (2009). Developing undergraduate research and inquiry research. York, UK: Higher Education Academy. Retrieved from https://www.heacademy.ac.uk/system/files/developingundergraduate final.pdf

Hemmi, A., Bayne, S., \& Land, R. (2009). The appropriation and repurposing of social technologies in higher education. Journal of Computer Assisted Learning, 25(1), 19-30. https://doi.org/10.1111/j.1365-2729.2008.00306.x

Jimoyiannis, A. (2012). Developing a pedagogical framework for the design and the implementation of eportfolios in educational practice. Themes in Science \& Technology Education, 5(1/2), 107-132. https://doi.org/10.1016/j.acra.2014.04.010

Jimoyiannis, A., Schiza, E. I., \& Tsiotakis, P. (2018). Students' self-regulated learning through online academic writing in a course blog. In D. Sampson, D. Ifenthaler, J. M. Spector, \& P. Isaías (Eds.), Digital technologies: Sustainable innovations for improving teaching and learning (pp. 111-129). Cham, Switzerland: Springer. https://doi.org/10.1007/978-3-319-73417-0

Jimoyiannis, A., \& Tsiotakis, P. (2016). Self-directed learning in e-portfolios: Analysing students' performance and learning presence. EAI EA Endorsed Transactions, 3(10), 1-9. https://doi.org/10.4108/eai.10-3-2016.151120

López Meneses, E., Vázquez-Cano, E., \& Jaén Martínez, A. (2017). Los portafolios digitales grupales: Un estudio diacrónico en la Universidad Pablo Olavide (2009-2015) [The group e-portfolio: A diachronic study at University Pablo de Olavide in Spain (2009-2015)]. Revista de Humanidades, 31, 123-152. https://doi.org/10.5944/rdh.31.2017.19076

Marín, V. I. (2017). Concept map for Theories and models of instructional design. Retrieved from https://cmapscloud.ihmc.us/viewer/cmap/1RHD92L2L-1BXCS9T-B3

Merrill, M. D. (2002). First principles of instruction. Educational Technology. Research and Development, 50(3), 43-59. https://doi.org/10.1007/BF02505024

Mor, Y., \& Mogilevsky, O. (2013a). Learning design studio: Educational practice as design inquiry of learning. In D. Hernández-Leo, T. Ley, R. Klamma, \& A. Harrer (Eds.), EC-TEL 2013: Scaling up Learning for Sustained Impact. Proceedings of the European Conference on Technology Enhanced Learning (pp. 233-245). Berlin, Germany: Springer-Verlag. https://doi.org/10.1007/978-3-64240814-4 19

Mor, Y., \& Mogilevsky, O. (2013b). The learning design studio: Collaborative design inquiry as teachers' professional development. Research in Learning Technology, 21. https://doi.org/10.3402/rlt.v21i0.22054

Muckel, P., Heidkamp, B., Kergel, D., Hartong, S., \& Brunner, S. (2014). Ensuring evidence in researchbased learning via ePortfolio. In S. Ravet et al. (Eds.), ePIC 2014. Proceedings of the 12th International ePortfolio and Identity Conference (pp. 96-100). Poitiers, France: Adpios.

Neira-Piñeiro, R., Villalustre, L., \& Del-Moral, E. M. (2013). Didactic experiences with blogs in training teachers: Writing in digital media to develop professional competences. International Journal of Technologies in Learning, 19(2), 51-64. https://doi.org/10.18848/2327-0144/CGP/v19i02/59007

O'Connell, T. S., \& Dyment, J. E. (2016). 'I'm just not that comfortable with technology': Student perceptions of and preferences for Web 2.0 technologies in reflective journals. Journal of Further and Higher Education, 40(3), 392-411. https://doi.org/10.1080/0309877X.2014.984594

Panke, S. (2014). E-portfolios in higher education settings: A literature review. In T. Bastiaens (Ed.), Proceedings of World Conference on E-Learning (pp. 1530-1539). San Diego, LA: Association for the Advancement of Computing in Education (AACE). Retrieved from https://www.learntechlib.org/primary/p/149108/

Reinmann, G. (2009). Wie praktisch ist die Universität? Vom situierten zum forschenden Lernen mit digitalen Medien [How practical is the university? From situational to exploratory learning with digital media]. Forschendes Lernen Im Studium - Konzepte Und Erfahrungen, 36-52. Retrieved from http://gabi-reinmann.de/wp-content/uploads/2009/08/Artikel_Forschendes situiertes_Lernen09.pdf

Reinmann, G. (2018). Reader zu Design-Based Research [Readings on design-based research]. Retrieved from https://gabi-reinmann.de/wp-content/uploads/2018/06/Reader_DBR Juni2018.pdf

Roberts, P., Maor, D., \& Herrington, J. (2016). ePortfolio-based learning environments: Recommendations for effective scaffolding of reflective thinking in higher education. Educational Technology and Society, 19(4), 22-33. Retrieved from https://www.j-ets.net/ETS/journals/19_4/3.pdf

Salinas, J., \& Marín, V. I. (2016). Trajectory of an institutional PLE in higher education based on an eportfolios system. In K. Terry \& A. Cheney (Eds.), Utilizing virtual and personal learning environments for optimal learning (pp. 132-156). Hershey, PA: IGI Global. https://doi.org/10.4018/978-1-4666-8847-6.ch007 
Senger, J., \& Kanthan, R. (2012). Student evaluations: Synchronous tripod of learning portfolio assessment-Self-Assessment, peer-assessment, instructor-assessment. Creative Education, 3(1), 155-163. https://doi.org/10.4236/ce.2012.31025

Shana, Z. A., \& Abulibdehb, E. S. (2015). Engaging students through blogs: Using blogs to boost a course experience. International Journal of Emerging Technologies in Learning, 10(1), 30-38. https://doi.org/10.3991/ijet.v10i1.4240

Tur, G., \& Castañeda, L. (2016). ePortafolio de proceso Vs. de producto como modalidades de implementación didáctica: la percepción del alumnado [Process vs. product ePortfolios: Two didactic implementation modalities: The student's perception]. International Journal of Educational Research and Innovation, 6, 187-200. Retrieved from https://www.upo.es/revistas/index.php/IJERI/article/view/1647

Tur, G., \& Marín, V. I. (2015). Exploring students' attitudes and beliefs towards e-Portfolios and technology in education. Enseñanza \& Teaching, 33(1), 57-82. https://doi.org/10.14201/et20153315782

Tur, G., \& Urbina, S. (2014). Blogs as eportfolio platforms in teacher education: Affordances and limitations derived from student teachers' perceptions and performance on their eportfolios. Digital Education Review, 26, 1-23. https://doi.org/10.1344/der.2014.0.1-23

van der Rijst, R. (2017). The transformative nature of research-based education: A thematic overview of the literature. In E. Bastiaens, J. van Tilburg, \& J. van Merriënboer (Eds.), Research-based learning: Case studies from Maastricht University (pp. 3-22). Cham, Switzerland: Springer. https://doi.org/10.1007/978-3-319-50993-8 1

Vázquez-Cano, E., López Meneses, E., \& Jaén Martínez, A. (2017). The group e-portfolio to improve teaching-learning process at university. Journal of E-Learning and Knowledge Society, 13(2), 65-76. https://doi.org/10.20368/1971-8829/1221

Voll, J. (2018). Bloggen in der Lehre-Beispiele und Ideen aus der Praxis [Teaching with blogs: Examples and ideas from practice]. In H. A. Mieg \& J. Lehmann (Eds.), Forschendes Lernen: ein Praxisbuch (pp. 394-410). Potsdam, Germany: Verlag der Fachhochschule Potsdam.

Yang, C., \& Chang, Y. S. (2012). Assessing the effects of interactive blogging on student attitudes towards peer interaction, learning motivation, and academic achievements. Journal of Computer Assisted Learning, 28(2), 126-135. https://doi.org/10.1111/j.1365-2729.2011.00423.x

Zubizarreta, J. (2009). The learning portfolio: Reflective practice for improving student learning. San Francisco, CA: Jossey Bass.

Corresponding author: Victoria I. Marín, victoria.marin@uni-oldenburg.de

Copyright: Articles published in the Australasian Journal of Educational Technology (AJET) are available under Creative Commons Attribution Non-Commercial No Derivatives Licence (CC BY-NC-ND 4.0). Authors retain copyright in their work and grant AJET right of first publication under CC BY-NC-ND 4.0.

Please cite as: Marín, V. I. (2020). Research-based learning in education studies: Design inquiry using group e-Portfolios based on blogs. Australasian Journal of Educational Technology, 36(1), 1-20. https://doi.org/10.14742/ajet.4523 


\section{Appendix - Student Questionnaire}

\section{SURVEY - USE OF THE GROUP BLOG FOR THE DEVELOPMENT OF THE PROJECT}

This questionnaire aims to evaluate your experience working with the group blog as e-Portfolio for: the enhancement of the development of the project according to your use and its support for collaboration, presentation and reflection. This is part of a study related to the use of digital tools for teaching and learning at the university, especially in research-based learning processes (https://www.uni-oldenburg.de/forschenat-studium/).

There are no correct or wrong answers. For each statement circle the option that corresponds to your opinion. The questionnaire is anonymous and your participation will not affect your relationship with the course (e.g., assessment) or with the university in any form. However, you are free to refuse to participate in this research study or to withdraw your consent and discontinue participation in the study at any time without penalty. Your return of this survey implies your consent to participate in this study.

Thank you very much for your collaboration. If you have any questions, you can contact Dr. Victoria Marín (victoria.marin@uni-oldenburg.de) at any time.

Circle or cross your degree of agreement or disagreement with the following statements from 1 (completely disagree) to 5 (completely agree):

\section{Statements}

1. The group blog was a suitable means to collect/store the information of our project.

2. The group blog was a proper means to reflect on the information collected and the progress.

3. The group blog was a suitable means to present the information in a $\begin{array}{llllll}1 & 2 & 3 & 4 & 5\end{array}$ structured way.

4. The group blog was a proper means to enhance collaboration inside my group.

5. The group blog was a useful support to visualize the progress of our $\begin{array}{llllll}1 & 2 & 3 & 4 & 5\end{array}$ project.

6. The group blog was a useful means to have an insight of what other $\begin{array}{lllll}1 & 2 & 3 & 4 & 5\end{array}$ groups were doing.

7. The group blog was easy to use for our purpose.

8. Personally, I consider Blogs a suitable means to support Designbased Research, i.e., the development of this project.
Scale

$\begin{array}{lllll}1 & 2 & 3 & 4 & 5\end{array}$

$\begin{array}{lllll}1 & 2 & 3 & 4 & 5\end{array}$

$\begin{array}{llll}2 & 3 & 4 & 5\end{array}$

2. 3

$\begin{array}{lllll}1 & 2 & 3 & 4 & 5 \\ 1 & 2 & 3 & 4 & 5\end{array}$


Answer the following questions about the use of the Blog briefly:

- How did your Group use the Blog? Can you identify changes in the use that you did of the Blog? Describe them briefly.

- How did you personally use the Blog, as member of your group? Did you agree beforehand on the roles for each of you related to the use of the Blog?

- What would you suggest to improve the use of Group Blogs for the development of a project?

Write down additional comments that you want to include about the blog for the development of the project: 